\title{
EMERGENCE AND GROWTH OF CORN AND SOYBEAN UNDER SALINE STRESS
}

\author{
Flávio Favaro Blanco ${ }^{1 *}$; Marcos Vinícius Folegatti²; Hans Raj Gheyi³; Pedro Dantas \\ Fernandes ${ }^{3}$ \\ ${ }^{1}$ Embrapa Meio Norte - Av. Duque de Caxias, 5650 - 64006-220 - Teresina, PI - Brasil \\ ${ }^{2}$ USP/ESALQ - Depto. de Engenharia Rural, C.P. 9 - 13418-900 - Piracicaba, SP - Brasil. \\ ${ }^{3}$ UFCG/CTRN - Unidade Acadêmica de Engenharia Agrícola, C.P. 10.087 - 58109-970 - Campina Grande, PB - Brasil. \\ *Corresponding author <flavio@cpamn.embrapa.br>
}

\begin{abstract}
Emergence and seedling growth may be severely affected by salinity, mainly for sensitive crops. The objective of the present study was to verify the tolerance of corn and soybean to the irrigation water salinity $\left(\mathrm{EC}_{\mathrm{i}}\right.$ ) during the emergence and initial development stages. Seeds of corn, hybrid 'AG-6690', and soybean, cv. 'Conquista', were sown in pots containing material from a sandyloam soil and irrigated with water of increasing salinity levels, from 0.3 to $5.9 \mathrm{dS} \mathrm{m}^{-1}$, giving nine levels of $\mathrm{EC}_{\mathrm{i}}$ obtained by the addition of an equivalent proportion of sodium and calcium chloride, except for $\mathrm{EC}_{\mathrm{i}}=0.3 \mathrm{dS} \mathrm{m}^{-1}$ (tap water). Emergence of corn was not affected by salinity but seedling development was reduced for $\mathrm{EC}_{\mathrm{i}}$ above $1.5 \mathrm{dS} \mathrm{m}^{-1}$. Emergence and growth of soybean were reduced by water salinity and the crop was more tolerant during the emergence $\left(\mathrm{EC}_{\mathrm{i}}=2.7 \mathrm{dS} \mathrm{m}^{-1}\right)$ than in the initial development $\left(\mathrm{EC}_{\mathrm{i}}=1.0 \mathrm{dS} \mathrm{\textrm {m } ^ { - 1 }}\right)$ stage. Salinity of soil solution $\left(\mathrm{EC}_{\mathrm{s}}\right)$ was linearly correlated to $\mathrm{EC}_{\mathrm{i}}$ and affected the growth of corn and soybean for $\mathrm{EC}_{\mathrm{s}}$ higher than 3 and $2 \mathrm{dS} \mathrm{m}^{-1}$, respectively.
\end{abstract}

Key words: Zea mays, Glycine max, salinity tolerance, soil solution

\section{EMERGÊNCIA E CRESCIMENTO DO MILHO E DA SOJA SOB ESTRESSE SALINO}

\begin{abstract}
RESUMO: A emergência e o crescimento inicial podem ser severamente afetados pela salinidade, principalmente para culturas sensíveis. O objetivo do presente estudo foi verificar a tolerância do milho e da soja à salinidade da água de irrigação $\left(\mathrm{CE}_{\mathrm{i}}\right)$ nas fases de emergência e desenvolvimento inicial das plantas. Sementes de milho, híbrido 'AG-6690', e soja, cv. 'Conquista', foram semeadas em vasos contendo material de solo franco-arenoso e irrigadas com água de níveis crescentes de salinidade, variando de 0,3 a 5,9 dS m$~ m^{-1}$, totalizando nove níveis de $\mathrm{CE}_{\mathrm{i}}$ obtidos pela adição de cloreto de sódio e de cálcio em proporções equivalentes, exceto para $\mathrm{CE}_{\mathrm{i}}=0,3 \mathrm{dS} \mathrm{m}^{-1}$ (água de torneira). A emergência do milho não foi afetada pela salinidade da água, mas o desenvolvimento das plantas foi reduzido para $\mathrm{CE}_{\mathrm{i}}$ acima de $1,5 \mathrm{dS} \mathrm{m}^{-1}$. A emergência e o crescimento da soja foram reduzidos pela salinidade, sendo mais tolerante na fase de emergência $\left(\mathrm{CE}_{\mathrm{i}}=2,7 \mathrm{dS} \mathrm{m}^{-1}\right)$ do que no desenvolvimento inicial das plantas

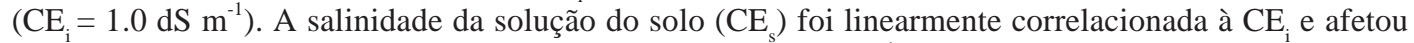
o crescimento do milho e da soja para $\mathrm{CE}_{\mathrm{s}}$ acima de 3 e $2 \mathrm{dS} \mathrm{m}^{-1}$, respectivamente.

Palavras-chave: Zea mays, Glycine max, tolerância, solução do solo
\end{abstract}

\section{INTRODUCTION}

Soybean (Glycine max L.) and corn (Zea mays L.) occupy, respectively, the second and third positions among the most cultivated crops in Brazil, with productions of 49 and 42 million tons in the year 2004; the sum of the areas harvested of these crops is close to 35 million hectars in the country (IBGE, 2005). The utilization of irrigation for corn and soybean production, mainly in the winter season, has increased substantially along years in Brazil (SEAGRO, 2005; Gomes, 2005; Moreira et al., 2000), but few studies have been carried out on the tolerance of these crops to salinity. Azevedo Neto \& Tabosa (2000) verified a significant reduction of dry matter of shoot for salinity levels above $9.6 \mathrm{dS} \mathrm{m}^{-1}$ in nutrient solution for a sensitive cultivar and over $12 \mathrm{dS} \mathrm{m}^{-1}$ for a tolerant cultivar of corn, indicating that there are differences of salinity tolerance among cultivars.

One of the primary effects of salt stress is that it delays germination and emergence; most crops are tolerant during germination but the young developing seedlings are susceptible to injury during emergence from the soil and during early development (Maas \& Grattan, 1999). Data reported by Essa (2002) showed that reduction of $8 \%$ in germination percentage and of 
$4 \%$ in plant height and in dry weight, at 45 days after planting of soybean cv. 'Lee', occurred for unitary increase of soil salinity (EC E $_{\mathrm{e}}$ above $0.5 \mathrm{dS} \mathrm{m}^{-1}$. The reduction of soybean growth under saline conditions can be attributed to $\mathrm{N}$ deficiency, once the number of nodules and their size are severely affected by the increasing salinity of the growing media (Singleton \& Bohlool, 1984), and to the reduction of the hydraulic conductivity of the root system (osmotic effect), with reduction of water delivery to the shoot (Joly, 1989).

The method usually employed to represent the tolerance of crops to salinity is the piecewise linear response model (Maas \& Hoffman, 1977):

$$
\mathrm{Yr}= \begin{cases}1 & 0 \leq \mathrm{c} \leq \mathrm{c}_{\mathrm{t}} \\ 1-\mathrm{s}\left(\mathrm{c}-\mathrm{c}_{\mathrm{t}}\right) & \mathrm{c}_{\mathrm{t}}<\mathrm{c} \leq \mathrm{c}_{0} \\ 0 & \mathrm{c}>\mathrm{c}_{0}\end{cases}
$$

where $\mathrm{Yr}$ is the relative yield, c is the mean salinity expressed as electrical conductivity of the solution in the root zone during the cultivation period $\left(\mathrm{dS} \mathrm{m}^{-1}\right), \mathrm{c}_{\mathrm{t}}$ is the threshold salinity $\left(\mathrm{dS} \mathrm{m}{ }^{-1}\right), \mathrm{c}_{0}$ is the salinity beyond which the yield is zero ( $\mathrm{dS} \mathrm{m}^{-1}$ ) and $\mathrm{s}$ is the absolute value of the slope of the response function between $\mathrm{c}_{\mathrm{t}}$ and $\mathrm{c}_{0}$.

Several experiments have been conducted along the years to quantify this type of response of the crops to salinity (Steppuhn et al., 2005; Khan et al., 2003; El-Haddad \& Noaman, 2001). Van Genuchten (1983) developed a software capable to make the adjustment of this model to data obtained in groups of experiments, which is particularly interesting for experiments repeated along years or seasons.

The objective of the present study was to determine the tolerance of corn and soybean to salinity of the irrigation water and of the soil solution during the emergence and seedling initial growth.

\section{MATERIAL AND METHODS}

The experiment was carried out in Piracicaba $\left(22^{\circ} 42^{\prime} \mathrm{S}\right.$ and $\left.47^{\circ} 37^{\prime} \mathrm{W}\right)$, SP, Brazil, in a greenhouse covered with polyethylene film with anti-aphid screens in the laterals. Seeds of corn and soybean were sown in pots, $0.35 \mathrm{~m}$ diameter at the top, containing $60 \mathrm{~kg}$ of a soil material collected from the 0-0.30 m layer of a sandy-loam Typic Hapludox. Perforations were made at the bottom of the pots and a gravel layer of 0.03 $\mathrm{m}$, covered with a polypropylene sheet, was displaced at the bottom to allow the drainage of the excess water. The pots were spaced $0.50 \times 1.00 \mathrm{~m}$.

The corn hybrid 'AG-6690' and of the soybean, cv. 'Conquista', were sown at a distance of
$0.15 \mathrm{~m}$ and $0.075 \mathrm{~m}$, in a single line, using four and three seeds in each sowing position, respectively. In this way, 12 seeds of corn and 15 of soybean were sown in each vase at a depth of $2 \mathrm{~cm}$ (Figure 1).

The treatments were composed of nine levels of electrical conductivity of the irrigation water $\left(\mathrm{EC}_{\mathrm{i}}=\right.$ $0.3,1.0,1.7,2.4,3.1,3.8,4.5,5.2$ and $5.9 \mathrm{dS} \mathrm{m}^{-1}$ ), which were obtained by the addition of $\mathrm{NaCl}$ and $\mathrm{CaCl}_{2}$ in the equivalent proportion of $1: 1$ (concentration of $\mathrm{NaCl}+\mathrm{CaCl}_{2}$ of $0.00,0.39,0.82,1.29,1.80,2.35,2.94$, 3.27 and $4.24 \mathrm{~g} \mathrm{~L}^{-1}$, respectively). Each vase was irrigated with the respective saline solution before planting in order to obtain levels of soil salinity. The experimental design consisted of completely randomized blocks, with a single factor $\left(\mathrm{EC}_{\mathrm{i}}\right)$ and with three replicates, totaling 27 pots for each crop.

Two tensiometers at 0.15 and $0.30 \mathrm{~m}$ depth and one soil solution extractor at $0.15 \mathrm{~m}$ depth were installed in each vase for irrigation control and monitoring of the electrical conductivity of the soil solution $\left(\mathrm{EC}_{\mathrm{s}}\right.$ ). Irrigations were accomplished by treatment whenever the mean matric potential of both tensiometers approached $-30 \mathrm{kPa}$, the water in each treatment being applied manually, without leaf wetting. The volume of water applied was calculated based on the water retention curve of the soil, allowing for a leaching fraction of at least 0.20 to avoid excessive build up of $\mathrm{EC}_{\mathrm{s}}$.

Soil solution was collected at the beginning of the experimental period and after each irrigation, when the electrical conductivity of the solution $\left(\mathrm{EC}_{\mathrm{s}}\right.$ ) was measured. Vacuum of about $-70 \mathrm{kPa}$ was applied to solution extractors after irrigation, when the soil matric potential was close to field capacity (about $-6 \mathrm{kPa}$ ) and soil solution was taken from the extractor $24 \mathrm{~h}$ after vacuum application. The concentrations of $\mathrm{NO}_{3}^{-}, \mathrm{K}^{+}$ and $\mathrm{Na}^{+}$in soil solution were also determined in the first sampling taken six days after sowing, using cardyion meters.
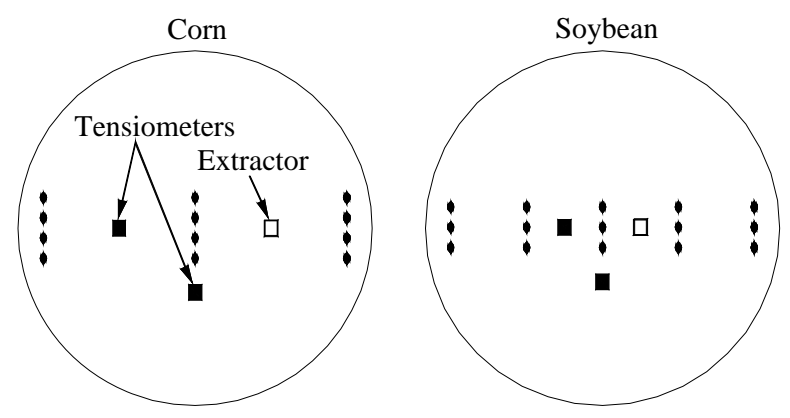

Figure 1 - Schematic representation of the planting positions of corn (with four seeds in each position) and soybean (three seeds per position) and the locations of tensiometers and soil solution extractor. 
The study was conducted during two growing seasons in order to obtain more precise results, once salinity tolerance may be affected by meteorological conditions and also by other factors, such as the salt accumulation in the soil profile along various cropping seasons. The first growing season was from $04 / 26 / 2003$ to $05 / 19 / 2003$ and the second from $05 / 23$ / 2003 to 07/01/2003. The smaller time of the first cultivation (23 days) in relation to the second (39 days) was due to the symptoms of phosphorus deficiency exhibited by the corn seedlings beginning from the $20^{\text {th }}$ DAS (day after sowing), which did not appear in the second cultivation period, in which $20 \mathrm{~g}$ of monoammonium phosphate and $3.3 \mathrm{~g} \mathrm{KCl}$ were applied to each vase, after diluting in the water used in the first irrigation.

During the first growing season, water was not applied immediately after sowing, because the soil was sufficiently wet due to the application of saline water for the salinization of the soil before planting. During the second season, $5 \mathrm{~L}$ of water were applied to each vase after sowing. Only one irrigation (5 L per vase) was added in the first growing period, at 10 DAS, and in the second growing period, besides the irrigation applied after sowing, $5 \mathrm{~L}$ of water were also applied at 25 DAS to each vase, giving a leaching fraction of about 0.35 , in an attempt to maintain an uniform $\mathrm{EC}_{\mathrm{s}}$ in the soil profile.

The number of emerged plants was determined everyday after sowing, which was accomplished up to the $14^{\text {th }}$ and $20^{\text {th }}$ DAS, respectively, for the first and second growing seasons, because the low temperatures during the second season delayed germination (Figure 2).

The emergence percentage (PE) was calculated from the total number of plants emerged in each vase and the speed of emergence (SE) was calculated as suggested by Maguire (1962):

$\mathrm{SE}=\frac{\mathrm{E}_{1}}{\mathrm{~N}_{1}}+\frac{\mathrm{E}_{2}}{\mathrm{~N}_{2}}+\ldots+\frac{\mathrm{E}_{\mathrm{n}}}{\mathrm{N}_{\mathrm{n}}}$

where $E_{1}, E_{2}$ and $E_{n}$ are the number of emerged plants, and $\mathrm{N}_{1}, \mathrm{~N}_{2}$ and $\mathrm{N}_{\mathrm{n}}$ are the number of days after sowing computed in the first, second and last countings, respectively. For the calculation of SE, the emergence period for each season corresponded to the day of maximum emergence for all pots, that is, the 13 DAS for the first season and 17 DAS for the second.

The seedlings of corn and soybean were collected from each vase at 10 and 20 DAS, respectively, for the first and second growing seasons, and only three seedlings of corn and five of soybean, that is, only one seedling in each sowing position were kept

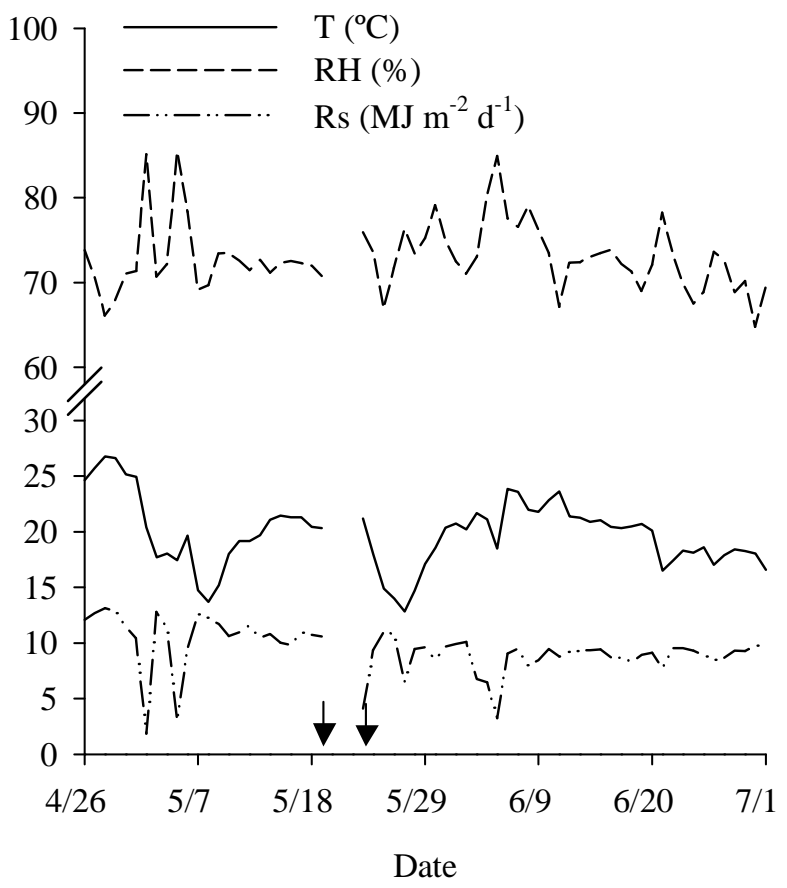

Figure 2 - Variations of temperature (T), relative humidity (RH) and global solar radiation (Rs) inside the greenhouse during the experimental period. The arrows indicate the end of the first growing season and the beginning of the second growing season.

in the pots. At the end of each cultivation period, the central seedlings of each vase (one seedling of corn and three seedlings of soybean) were collected. The seedlings were cut at the soil surface level and ovendried at $60^{\circ} \mathrm{C}$, and the mean dry weight per plant was evaluated. The dry weight of soybean was computed separately for stem and leaves in the last sampling for the two growing periods. The absolute (AGR) and relative (RGR) growth rates were determined as recommended by Benincasa (1988):

$$
\begin{aligned}
& \text { AGR }=\frac{D_{2}-D_{1}}{T_{2}-T_{1}} \\
& \text { RGR }=\frac{\ln \left(D_{2}\right)-\ln \left(D_{1}\right)}{T_{2}-T_{1}}
\end{aligned}
$$

where $\mathrm{D}_{1}$ and $\mathrm{D}_{2}$ are the mean dry weights $(\mathrm{g})$ in the first and second collections, respectively, and $\mathrm{T}_{1}$ and $\mathrm{T}_{2}$ refer to time interval (days after sowing) of the collections for each growing period. The leaf weight ratio (LWR) was determined dividing the leaf dry weight by the total dry weight. Plant height was measured before cutting by measuring the distance between the soil surface and the growing point for soybean and, for corn, the leaves were extended upwards and the maximum distance between soil surface and leaf tip was measured. 
The parameters $s$ and $c_{t}$ (equation 1 ) were estimated using the software SALT (Van Genuchten, 1983), which makes the adjustment of the regression model by the piecewise linear regression method. The adjustments of the PE and SE were performed only in relation to $\mathrm{EC}_{\mathrm{i}}$, once $\mathrm{EC}_{\mathrm{s}}$ in the shallower layer of the soil may be assumed to be equal to the salinity of the water that infiltrates in the soil (Rhoades et al., 2000); thus, as seedlings were sown at $2 \mathrm{~cm}$ depth, the $\mathrm{EC}_{\mathrm{i}}$ and $\mathrm{EC}_{\mathrm{s}}$ are the same for the emergence stage. The dry weight of the seedlings was confronted with $\mathrm{EC}_{\mathrm{i}}$ and with the mean values of $\mathrm{EC}_{\mathrm{s}}$ determined for each growing season.

\section{RESULTS AND DISCUSSION}

The percentage of emergence (PE) and the speed of emergence (SE) of corn were not affected by the electrical conductivity of the irrigation water $\left(E_{i}\right)$, while for soybean, $E_{i}$ responded to both variables (Table 1). Effects of EC $\mathrm{C}_{\mathrm{i}}$ on PE and SE for soybean were practically the same and they were reduced for the second growing season for all levels of $\mathrm{EC}_{\mathrm{i}}$ due to the higher salinity of the soil solution as a result of salt accumulation in the soil profile with the successive irrigations (Figure 2). Mean EC threshold (c) for relative values of $\mathrm{PE}$ and $\mathrm{SE}$ for soybean was about $2.7 \mathrm{dS} \mathrm{m}^{-1}$, with a reduction of $20 \%$ for each unitary increase of $\mathrm{EC}_{\mathrm{i}}$ above $\mathrm{c}_{\mathrm{t}}$; the emergence was completely inhibited when $\mathrm{EC}_{\mathrm{i}}$ was close to $8.0 \mathrm{dS} \mathrm{m}^{-1}$, determined by extrapolation $\left(c_{0}=7.9 \mathrm{dS} \mathrm{m}^{-1}\right)$.

The results for corn are in agreement with Maas (1984), who stated that corn may tolerate high salinity (up to $24 \mathrm{dS} \mathrm{m}^{-1}$ ) in soil saturation extract (EC ${ }_{\mathrm{e}}$ ) at germination. In the present study, although the data refers to $\mathrm{EC}_{\mathrm{i}}, \mathrm{EC}_{\mathrm{e}}$ was below the cited threshold value, once the highest electrical conductivity of the soil solution (EC) was $7.12 \mathrm{dS} \mathrm{m}^{-1}$ and it probably was higher than EC because only highly soluble salts were used.

The ability of a seed to germinate and emerge under salt stress indicates that it has a genetic potential for salt tolerance, at least at this stage in the life cycle, but this does not necessarily indicate that a seedling germinated under salt stress could continue under salt stress and that the plant could complete its life cycle (Essa, 2002).

Salinity affected the plant height $(\mathrm{PH})$, total dry weight (TDW) and absolute growth rate (AGR) of corn in both growing periods (Table 2). Relative values of TDW and AGR were more sensible to $\mathrm{EC}_{\mathrm{i}}$ than $\mathrm{PH}$; the threshold $\mathrm{EC}_{\mathrm{i}}$ for TDW and AGR was 1.5

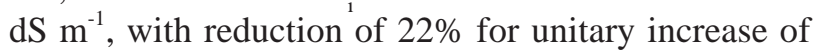
EC $_{\mathrm{i}}$ above $1.5 \mathrm{dS} \mathrm{m}^{-1}$, while $\mathrm{c}_{\mathrm{t}}$ and $\mathrm{s}$ for $\mathrm{PH}$ were 1.9 $\mathrm{dS} \mathrm{m}^{-1}$ and $13 \%$, respectively (Table 3 ).
The absence of response of RGR shows that the growth obtained relative to the amount of tissue present was the same for all levels of $\mathrm{EC}_{\mathrm{i}}$, that is, the growth potential of corn 'AG6690'seedling under low and high salinity was the same. Otherwise, the growth speed was lower for high $\mathrm{EC}_{\mathrm{i}}$, once AGR was reduced for $\mathrm{EC}_{\mathrm{i}}$ above $1.5 \mathrm{dS} \mathrm{m}^{-1}$.

Dry weight of leaf (DWL) and stem (DWS) of soybean were affected by $\mathrm{EC}_{\mathrm{i}}$ in the first growing period, as well as total dry weight (TDW), but PH, LWR and the physiological indexes were not sensitive to salinity (Table 4). During the second growing period, only LWR was not affected by salinity.

A little increase in DWL, DWS and TDW occurred for the $\mathrm{EC}_{\mathrm{i}}$ of $1.0 \mathrm{dS} \mathrm{m}^{-1}$ in relation to tap wa-

Table 1 - Percentage (PE) and speed (SE) of emergence for corn and soybean seeds for different levels of electrical conductivity of the irrigation water $\left(\mathrm{EC}_{\mathrm{i}}\right.$ ) and summary of the analysis of variance for each growing season.

\begin{tabular}{|c|c|c|c|c|}
\hline \multirow{2}{*}{$\mathrm{EC}_{\mathrm{i}}$} & \multicolumn{2}{|c|}{ Season 1} & \multicolumn{2}{|c|}{ Season 2} \\
\hline & PE & SE & $\mathrm{PE}$ & SE \\
\hline $\mathrm{dS} \mathrm{m^{-1 }}$ & $\%$ & seeds day ${ }^{-1}$ & $\%$ & seeds day \\
\hline \multicolumn{5}{|c|}{ Corn } \\
\hline 0.3 & 97 & 2.2 & 83 & 1.3 \\
\hline 1.0 & 92 & 1.9 & 81 & 1.2 \\
\hline 1.7 & 89 & 1.9 & 92 & 1.3 \\
\hline 2.4 & 83 & 1.7 & 78 & 1.1 \\
\hline 3.1 & 86 & 1.8 & 83 & 1.2 \\
\hline 3.8 & 67 & 1.5 & 86 & 1.1 \\
\hline 4.5 & 89 & 1.8 & 89 & 1.2 \\
\hline 5.2 & 72 & 1.4 & 86 & 1.1 \\
\hline 5.9 & 58 & 1.1 & 78 & 1.0 \\
\hline F Test ${ }^{\S}$ & $\mathrm{ns}$ & $\mathrm{ns}$ & ns & ns \\
\hline $\mathrm{CV}^{\#}(\%)$ & 19.3 & 26.4 & 16.3 & 17.6 \\
\hline \multicolumn{5}{|c|}{ Soybean } \\
\hline 0.3 & 98 & 3.8 & 56 & 1.1 \\
\hline 1.0 & 89 & 3.0 & 76 & 1.5 \\
\hline 1.7 & 93 & 3.3 & 78 & 1.5 \\
\hline 2.4 & 96 & 3.3 & 87 & 1.6 \\
\hline 3.1 & 87 & 3.0 & 62 & 1.1 \\
\hline 3.8 & 76 & 2.6 & 62 & 1.1 \\
\hline 4.5 & 80 & 2.4 & 40 & 0.7 \\
\hline 5.2 & 56 & 1.6 & 31 & 0.5 \\
\hline 5.9 & 47 & 1.3 & 7 & 0.1 \\
\hline F Test ${ }^{\S}$ & $* *$ & $* *$ & $* *$ & $* *$ \\
\hline $\mathrm{CV}^{\#}(\%)$ & 14.8 & 19.1 & 24.5 & 28.6 \\
\hline
\end{tabular}

${ }^{\S} \mathrm{ns}$ non-significant; **significant at 0.01 by the test $\mathrm{F}$; ${ }^{*} \mathrm{CV}$ coefficient of variation 
Table 2 - Means and F test for electrical conductivity of the soil solution $\left(\mathrm{EC}_{\mathrm{s}}\right)$, plant height $(\mathrm{PH})$, total dry weight (TDW) and absolute (AGR) and relative (RGR) growth rates of corn irrigated with waters of different salinities $\left(\mathrm{EC}_{\mathrm{i}}\right)$.

\begin{tabular}{|c|c|c|c|c|c|}
\hline $\mathrm{EC}_{\mathrm{i}}$ & $\mathrm{EC}_{\mathrm{s}}$ & $\mathrm{PH}$ & TDW & AGR & RGR \\
\hline --- dS m- & $n^{-1}---$ & $\mathrm{cm}$ & $\mathrm{mg}$ & $\mathrm{mg} \mathrm{d}^{-1}$ & $m g \mathrm{mg}^{-1} \mathrm{~d}^{-1}$ \\
\hline \multicolumn{6}{|c|}{ Growing season 1} \\
\hline 0.3 & 0.68 & 38.7 & 569 & 48 & 0.152 \\
\hline 1.0 & 1.02 & 37.5 & 410 & 34 & 0.153 \\
\hline 1.7 & 1.94 & 33.8 & 396 & 29 & 0.119 \\
\hline 2.4 & 2.34 & 29.0 & 300 & 24 & 0.146 \\
\hline 3.1 & 2.90 & 28.3 & 387 & 31 & 0.146 \\
\hline 3.8 & 3.91 & 36.7 & 398 & 35 & 0.180 \\
\hline 4.5 & 4.17 & 30.5 & 396 & 35 & 0.182 \\
\hline 5.2 & 4.39 & 27.5 & 266 & 22 & 0.153 \\
\hline 5.9 & 5.07 & 20.8 & 151 & 11 & 0.095 \\
\hline F Test ${ }^{\S}$ & $* *$ & $*$ & $* *$ & $*$ & ns \\
\hline $\mathrm{CV}^{\#}(\%)$ & 13.9 & 17.8 & 27.2 & 36.5 & 30.0 \\
\hline \multicolumn{6}{|c|}{ Growing season 2} \\
\hline 0.3 & 0.87 & 100.7 & 12730 & 654 & 0.195 \\
\hline 1.0 & 1.66 & 102.7 & 10970 & 562 & 0.190 \\
\hline 1.7 & 3.51 & 102.0 & 12680 & 651 & 0.196 \\
\hline 2.4 & 3.88 & 97.3 & 9750 & 501 & 0.193 \\
\hline 3.1 & 4.27 & 83.3 & 5620 & 287 & 0.184 \\
\hline 3.8 & 5.62 & 73.7 & 4270 & 218 & 0.186 \\
\hline 4.5 & 6.07 & 72.7 & 5490 & 283 & 0.199 \\
\hline 5.2 & 6.97 & 50.4 & 1270 & 63 & 0.126 \\
\hline 5.9 & 7.12 & 47.3 & 1530 & 140 & 0.167 \\
\hline F Test ${ }^{\S}$ & $* *$ & $* *$ & $* *$ & $* *$ & ns \\
\hline $\mathrm{CV}^{\#}(\%)$ & 14.1 & 11.2 & 41.6 & 41.7 & 34.3 \\
\hline
\end{tabular}

${ }^{\S}$ ns non-significant; *, ** significant at 0.05 and 0.01 level by the test $\mathrm{F}$, respectively; ${ }^{*} \mathrm{CV}$ - coefficient of variation.

ter $\left(0.3 \mathrm{dS} \mathrm{m}^{-1}\right)$ for both growing periods. Generally $\mathrm{Na}^{+}$is not essential for most plants, although their growth may be stimulated at low $\mathrm{Na}^{+}$concentrations because it might serve as an osmoticum in the vacuole, reducing plants need for $\mathrm{K}^{+}$(Marschner, 1995). Thus, for plants irrigated with water of $1.0 \mathrm{dS} \mathrm{m}^{-1}$, the soybean seedlings may have accumulated $\mathrm{Na}^{+}$in their vacuoles, which partly could have compensated the lower $\mathrm{K}^{+}$uptake and promoted a higher growth than the plants irrigated with tap water.

Besides the ability of some plants to accumulate salts in cells in order to reduce the osmotic potential under saline stress (Munns, 2002), moderate and high levels of $\mathrm{NaCl}$ may lead to toxicity by $\mathrm{Na}^{+}$ and $\mathrm{Cl}^{-}$(Tester \& Davenport, 2003) and growth reduces according to the severity of the imposed stress
Table 3 - Values of threshold salinity (c), slope (s) and salinity for zero yield $\left(\mathrm{c}_{0}\right)$ adjusted from the electrical conductivity of the irrigation water $\left(\mathrm{EC}_{\mathrm{i}}\right)$ and soil solution (EC ) by the model SALT (Van Genuchten, 1983), for traits (relative values) of corn and soybean.

\begin{tabular}{|c|c|c|c|c|c|c|}
\hline \multirow{2}{*}{ Variable ${ }^{\#}$} & \multicolumn{3}{|c|}{$\mathrm{EC}_{\mathrm{i}}$} & \multicolumn{3}{|c|}{$\mathrm{EC}_{\mathrm{s}}$} \\
\hline & $c_{t}$ & $\mathrm{~s}$ & $\mathrm{c}_{0}$ & $c_{t}$ & $\mathrm{~s}$ & $\mathrm{c}_{0}$ \\
\hline & \multicolumn{6}{|c|}{ dS $m^{-1}$} \\
\hline \multicolumn{7}{|c|}{ Soybean } \\
\hline $\mathrm{PE}$ & 2.8 & 0.19 & 7.9 & - & - & - \\
\hline SE & 2.6 & 0.20 & 7.7 & - & - & - \\
\hline PH & 0.9 & 0.14 & 8.1 & 2.5 & 0.13 & 10.0 \\
\hline DWL & 1.0 & 0.21 & 5.6 & 2.1 & 0.18 & 7.6 \\
\hline DWS & 0.8 & 0.22 & 5.4 & 2.0 & 0.18 & 7.4 \\
\hline TDW & 1.0 & 0.22 & 5.5 & 2.1 & 0.18 & 7.5 \\
\hline AGR & 0.6 & 0.22 & 5.2 & 1.6 & 0.17 & 7.6 \\
\hline RGR & 2.4 & 0.16 & 8.5 & 4.6 & 0.20 & 9.7 \\
\hline \multicolumn{7}{|c|}{ Corn } \\
\hline PH & 1.9 & 0.13 & 9.6 & 3.5 & 0.14 & 10.7 \\
\hline TDW & 1.5 & 0.22 & 6.0 & 3.0 & 0.22 & 7.6 \\
\hline AGR & 1.5 & 0.22 & 6.1 & 2.7 & 0.18 & 8.3 \\
\hline
\end{tabular}

" $\mathrm{PE}=$ Percentage of emergence; $\mathrm{SE}=$ speed of emergence; $\mathrm{PH}=$ plant height; DWL=dry weight of leaves; DWS=dry weight of stem;

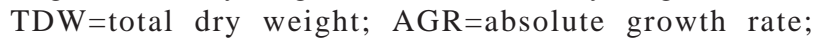
$\mathrm{RGR}=$ relative growth rate.

(Silva et al., 2003; Agong et al., 2003, Kaya et al., 2003). The soybean variety 'Conquista' presented no ability in adjusting the photosynthetic capacity in high saline conditions; the LWR was not affected by salinity, thus the leaf area decreased with reduction of the DWL.

The mean reduction of DWL, DWS and TDW for soybean was of $22 \%$ for each unitary increase in $E_{\mathrm{i}}$ above $1.0 \mathrm{dS} \mathrm{m}^{-1}$ and the $\mathrm{EC}_{\mathrm{i}}$ of $5.5 \mathrm{dS} \mathrm{m}^{-1}$ resulted in no plant development (Table 3). The lower $\mathrm{c}_{\mathrm{t}}$ and higher s for AGR $\left(0.6 \mathrm{dS} \mathrm{m} \mathrm{m}^{-1}\right.$ and 0.22 , respectively) than for RGR (2.4 dS m ${ }^{-1}$ and 0.16 , respectively) reveals that the growing speed of the plants was more affected by salinity than the growth potential. Therefore, soybean growth is delayed by salinity and high $\mathrm{EC}_{\mathrm{i}}$ also affects the dry matter accumulation in relation to preexisting dry matter. The results of this study are in agreement with those of Moraes \& Menezes (2003) and Wang \& Shannon (1999), who reported that shoot growth of soybean is more affected by salinity than the PE.

The $\mathrm{EC}_{\mathrm{s}}$ was linearly correlated to $\mathrm{EC}_{\mathrm{i}}$ for both crops, being higher for the second than for the first growing period (Figure 3). When data of each variable were adjusted as a function of $\mathrm{EC}_{\mathrm{s}}$ (Table 3) it 
Table 4 - Means and results of test F for electrical conductivity of the soil solution (EC) ( $_{\mathrm{s}}$, plant height (PH), dry weight of leaves (DWL), stem (DWS) and total (TDW), absolute (AGR) and relative (RGR) growth rates and leaf weight ratio (LWR) of soybean irrigated with waters of different salinities $\left(\mathrm{EC}_{\mathrm{i}}\right)$.

\begin{tabular}{|c|c|c|c|c|c|c|c|c|}
\hline $\mathrm{EC}_{\mathrm{i}}$ & $\mathrm{EC}_{\mathrm{s}}$ & $\mathrm{PH}$ & DWL & DWS & TDW & AGR & RGR & LWR \\
\hline -.....- & - & $\mathrm{cm}$ & $\mathrm{mg}$ & \multicolumn{3}{|c|}{ (no $\mathrm{mg} \mathrm{d}^{-1} \ldots \ldots \ldots \ldots$} & $m g \mathrm{mg}^{-1} \mathrm{~d}^{-1}$ & \\
\hline \multicolumn{9}{|c|}{ Growing season 1} \\
\hline 0.3 & 1.1 & 18.7 & 307 & 137 & 444 & 29 & 0.098 & 0.69 \\
\hline 1.0 & 1.4 & 19.3 & 333 & 133 & 466 & 33 & 0.113 & 0.71 \\
\hline 1.7 & 1.8 & 18.3 & 286 & 125 & 411 & 26 & 0.094 & 0.70 \\
\hline 2.4 & 2.2 & 18.7 & 273 & 123 & 396 & 25 & 0.093 & 0.69 \\
\hline 3.1 & 3.4 & 17.7 & 271 & 112 & 383 & 25 & 0.094 & 0.71 \\
\hline 3.8 & 3.8 & 17.8 & 289 & 126 & 415 & 29 & 0.115 & 0.70 \\
\hline 4.5 & 4.0 & 16.0 & 249 & 103 & 352 & 24 & 0.107 & 0.71 \\
\hline 5.2 & 4.6 & 17.3 & 240 & 104 & 344 & 18 & 0.097 & 0.70 \\
\hline 5.9 & 4.9 & 14.2 & 199 & 84 & 283 & 24 & 0.096 & 0.70 \\
\hline F Test ${ }^{\S}$ & $* *$ & $\mathrm{~ns}$ & $* *$ & $* *$ & $* *$ & ns & ns & ns \\
\hline $\mathrm{CV}^{\#}(\%)$ & 15.8 & 12.8 & 24.4 & 21.7 & 22.8 & 16.4 & 16.9 & 2.2 \\
\hline \multicolumn{9}{|c|}{ Growing season 2} \\
\hline 0.3 & 0.8 & 45.0 & 2548 & 1592 & 4140 & 238 & 0.143 & 0.61 \\
\hline 1.0 & 2.1 & 44.7 & 3102 & 1693 & 4796 & 236 & 0.145 & 0.65 \\
\hline 1.7 & 2.9 & 38.6 & 2016 & 1117 & 3132 & 152 & 0.136 & 0.64 \\
\hline 2.4 & 4.0 & 37.9 & 2040 & 1129 & 3169 & 157 & 0.149 & 0.65 \\
\hline 3.1 & 5.3 & 31.2 & 1232 & 602 & 1834 & 86 & 0.118 & 0.67 \\
\hline 3.8 & 5.8 & 30.1 & 1113 & 536 & 1649 & 95 & 0.126 & 0.68 \\
\hline 4.5 & 6.4 & 20.9 & 567 & 325 & 892 & 31 & 0.086 & 0.65 \\
\hline 5.2 & 6.6 & 14.3 & 333 & 132 & 465 & - & - & 0.71 \\
\hline 5.9 & 7.1 & 17.0 & 270 & 140 & 410 & - & - & 0.66 \\
\hline F Test ${ }^{\S}$ & $* *$ & $* *$ & $* *$ & $* *$ & $* *$ & $* *$ & $* *$ & ns \\
\hline $\mathrm{CV}^{\#}(\%)$ & 10.5 & 11.7 & 20.1 & 23.5 & 14.8 & 8.4 & 5.6 & 8.3 \\
\hline
\end{tabular}

${ }^{\S}$ ns Non-significant; **significant at 0.01 level by the test F; ${ }^{*} \mathrm{CV}$ - coefficient of variation.
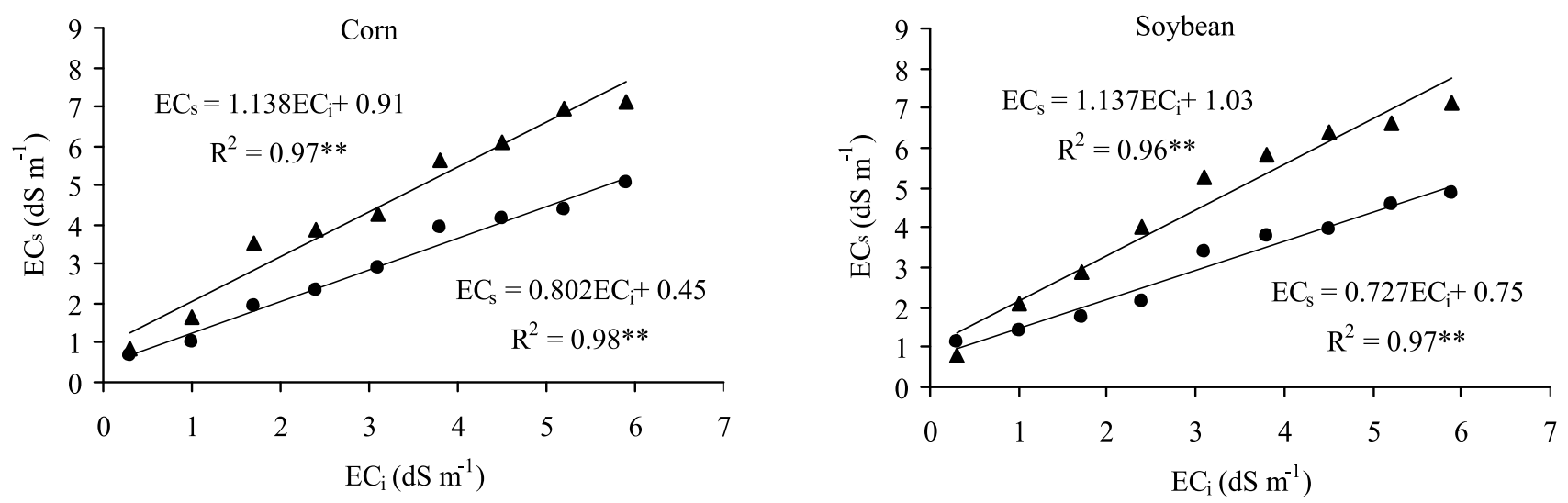

Figure 3 - Mean electrical conductivity of soil solution $\left(\mathrm{EC}_{\mathrm{s}}\right)$ in the first $(\bullet)$ and second $(\boldsymbol{\Delta})$ growing periods of corn and soybean, as a function of electrical conductivity of the irrigation water $\left(\mathrm{EC}_{\mathrm{i}}\right)$.

was observed that the salinity threshold was about two times higher than $\mathrm{c}_{\mathrm{t}}$ for data adjusted to $\mathrm{EC}_{\mathrm{i}}$, as a result of the concentration factor (the concentration of salts in soil after successive irrigations).
Willadino et al. (1994) tested eight cultivars of corn in relation to salinity and all of them survived and had heights above $1.5 \mathrm{~m}$ when grown in saline soil with electrical conductivity of the saturation extract $\left(\mathrm{EC}_{\mathrm{e}}\right)$ 
of $9.9 \mathrm{dS} \mathrm{m}^{-1}$. Considering that the $\mathrm{EC}_{\mathrm{e}}$ is generally lower than EC (Blanco, 2004; Eymar et al., 2001; Rieu et al., 1998), the results of total dry weight of corn in relation to $\mathrm{EC}_{\mathrm{s}}$ (Table 3) allow us to conclude that seedling development at $\mathrm{EC}_{\mathrm{e}}$ of $9.9 \mathrm{dS} \mathrm{m}^{-1}$ is not possible, agreeing with Maas \& Hoffman (1977), who reported that at $\mathrm{EC}_{\mathrm{e}}$ of $10 \mathrm{dS} \mathrm{m}^{-1}$ was corn growth ceases.

In the emergence stage the soybean 'Conquista' was less sensible to salinity of the irrigation water than in the seedling growth stage. Waters up to $2.8 \mathrm{dS} \mathrm{m}^{-1}$ may be used for germination without reduction of the stand, but after emergence $\mathrm{EC}_{\mathrm{i}}$ above $1.0 \mathrm{dS} \mathrm{m}^{-1}$ should be avoided, which lead to severe damage for plant growth. Although little reductions of emergence of corn 'AG6690' were observed for the mean data, it was not sensitive to salinity; on the other hand, irrigation with water of $\mathrm{EC}_{\mathrm{i}}$ above $1.5 \mathrm{dS} \mathrm{m}^{-1}$ is deleterious for seedling growth with severe reduction of plant development.

The optimal concentrations of $\mathrm{NO}_{3}{ }^{-}$and $\mathrm{K}^{+}$in the early half of the season for most crops are 220330 and 20-60 $\mathrm{mg} \mathrm{L}^{-1}$, respectively (Burt et al., 1998; Tisdale et al., 1993). At the beginning of each growing period, the concentrations of $\mathrm{NO}_{3}^{-}$and $\mathrm{K}^{+}$in soil solution were in this range for most treatments (Table 5). The concentration of $\mathrm{Na}^{+}$in soil solution increased linearly with $\mathrm{EC}_{\mathrm{i}}$ and the concentration for each treatment was, on average, $73 \%$ higher in the second growing period in comparison to the first (Figure 4). The increase in concentration of $\mathrm{K}^{+}$with $\mathrm{EC}_{\mathrm{i}}$ could be attributed to the replacement of $\mathrm{K}^{+}$from the exchange complex by $\mathrm{Na}^{+}$, which allowed higher $\mathrm{K}^{+}$in soil solution.

The results of this study show that the response of corn and soybean to salinity is quite different. While soybean is more tolerant to salinity than corn
Table 5 - Concentration of $\mathrm{NO}_{3}^{-}$, $\mathrm{K}^{+}$and $\mathrm{Na}^{+}$in soil solution at the beginning of each growing period of corn and soybean, for each electrical conductivity of the irrigation water $\left(\mathrm{EC}_{\mathrm{i}}\right)$.

\begin{tabular}{|c|c|c|c|c|c|c|}
\hline $\mathrm{EC}_{\mathrm{i}}$ & $\mathrm{NO}_{3}^{-}$ & $\mathrm{K}^{+}$ & $\mathrm{Na}^{+}$ & $\mathrm{NO}_{3}^{-}$ & $\mathrm{K}^{+}$ & $\mathrm{Na}^{+}$ \\
\hline $\mathrm{dS} \mathrm{m}^{-1}$ & \multicolumn{6}{|c|}{ - } \\
\hline & \multicolumn{3}{|c|}{ Growing season 1} & \multicolumn{3}{|c|}{ Growing season 2} \\
\hline & \multicolumn{6}{|c|}{ Corn } \\
\hline 0.3 & 217 & 34 & 37 & 228 & 32 & 45 \\
\hline 1.0 & 230 & 71 & 76 & 177 & 79 & 93 \\
\hline 1.7 & 177 & 98 & 167 & 193 & 96 & 247 \\
\hline 2.4 & 186 & 78 & 183 & 200 & 120 & 330 \\
\hline 3.1 & 83 & 103 & 223 & 110 & 125 & 445 \\
\hline 3.8 & 185 & 103 & 325 & 280 & 125 & 605 \\
\hline 4.5 & 240 & 160 & 387 & 280 & 150 & 583 \\
\hline 5.2 & 170 & 133 & 433 & 215 & 145 & 860 \\
\hline 5.9 & 183 & 133 & 647 & 270 & 130 & 950 \\
\hline F Test ${ }^{\S}$ & ns & $*$ & $* *$ & ns & ns & $* *$ \\
\hline \multirow[t]{2}{*}{$\mathrm{CV}^{\#}(\%)$} & 39.0 & 34.8 & 23.4 & 53.5 & 31.8 & 26.2 \\
\hline & \multicolumn{6}{|c|}{ Soybean } \\
\hline 0.3 & 145 & 50 & 30 & 177 & 47 & 38 \\
\hline 1.0 & 207 & 96 & 74 & 120 & 100 & 120 \\
\hline 1.7 & 144 & 75 & 105 & 165 & 83 & 200 \\
\hline 2.4 & 112 & 50 & 147 & 220 & 73 & 290 \\
\hline 3.1 & 147 & 107 & 250 & 235 & 127 & 485 \\
\hline 3.8 & 167 & 167 & 293 & 247 & 180 & 513 \\
\hline 4.5 & 133 & 114 & 327 & 247 & 177 & 733 \\
\hline 5.2 & 106 & 102 & 487 & 345 & 170 & 675 \\
\hline 5.9 & 150 & 88 & 505 & 290 & 140 & 830 \\
\hline $\mathrm{F}$ Test ${ }^{\S}$ & $\mathrm{ns}$ & $* *$ & $* *$ & ns & $*$ & $* *$ \\
\hline $\mathrm{CV}^{\#}(\%)$ & 45.0 & 31.4 & 28.2 & 30.5 & 37.0 & 24.0 \\
\hline
\end{tabular}

${ }^{\S} \mathrm{ns}, *, * *$ Non-significant and significant at 0.05 and 0.01 of probability by the test $\mathrm{F}$, respectively; ${ }^{*} \mathrm{CV}$ - coefficient of variation

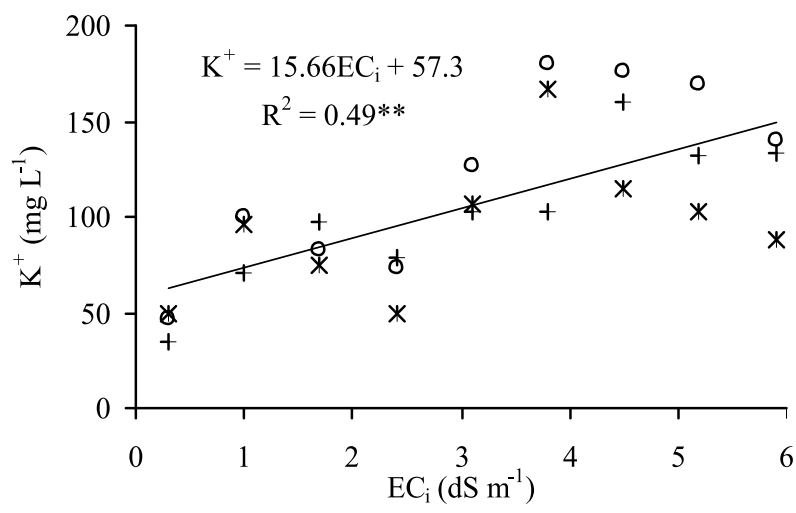

Figure 4 - Concentration of $\mathrm{Na}^{+}$and $\mathrm{K}^{+}$in the soil solution for corn (C) and soybean (S) in the first (GP1) and second (GP2) growing periods, as a function of electrical conductivity of the irrigation water $\left(\mathrm{EC}_{\mathrm{i}}\right)$. 
from the seedling stage to maturity (Ayers, \& Westcot, 1985), the tolerance of corn overcame soybean from planting to seedling development stages. Therefore, an irrigation management strategy should be taken to maximize yield in the corn-soybean crop rotation when using saline water. Saline water could be used to produce soybean, being applied after crop establishment, and during the germination of corn, but a reduction of soil salinity is required to obtain satisfactory production of corn. Thus, corn-soybean crop rotation is advantageous because it allows farmers to use poor quality water and/or reuse the drainage water for irrigation of these crops, but the irrigation management must to be accomplished to avoid high soil salinity during the germination stage for soybean and latter stages of corn development.

\section{CONCLUSIONS}

Electrical conductivity of the irrigation water up to $5.9 \mathrm{dS} \mathrm{m}^{-1}$ does not reduce the emergence percentage and the speed of emergence of corn 'AG6690', but reduces the emergence percentage and speed of emergence of soybean 'Conquista', with reduction of $20 \%$ for unitary increase irrigation water salinity above $2.7 \mathrm{dS} \mathrm{m}^{-1}$;

Growth of corn and soybean seedlings reduces with irrigation water salinity above 1.5 and $1.0 \mathrm{dS} \mathrm{m}^{-1}$ and with electrical conductivity of soil solution above 3.0 and $2.0 \mathrm{dS} \mathrm{m}^{-1}$, respectively;

Corn is capable of maintaining the same growth rate in relation to the preexisting dry matter even under high saline conditions, while the relative growth rate of soybean is reduced for irrigation water salinity and soil solution salinity above $2.4 \mathrm{dS} \mathrm{m}^{-1}$ and $4.6 \mathrm{dS} \mathrm{m}^{-1}$, respectively.

\section{REFERENCES}

AGONG, S.G.; KINGETSU, M.; YOSHIDA, Y.; YAZAWA, S.; MASUDA, M. Response of tomato genotypes to induced salt stress. African Crop Science Journal, v.11, p.133-142, 2003.

AYERS, R.S.; WESTCOT, D.W. Water quality for agriculture. Rome: FAO, 1985. 174p. (Irrigation and Drainage Paper, 29 rev.1).

AZEVEDO NETO, A.D.; TABOSA, J.N. Estresse salino em plântulas de milho: Parte I análise do crescimento. Revista Brasileira de Engenharia Agrícola e Ambiental, v.4, p.159164, 2000.

BLANCO, F.F. Tolerância do tomateiro à salinidade sob fertirrigação e calibração de medidores de íons específicos para determinação de nutrientes na solução do solo e na planta. Piracicaba: USP/ ESALQ, 2004. 115p. (Tese - Doutorado).

BENINCASA, M.M.P. Análise de crescimento de plantas (noções básicas). Jaboticabal: FUNEP, 1988. 41p.

BURT, C.; O’CONNOR, K.; RUEHR, T. Fertigation. San Luis Obispo: The Irrigation Training \& Research Center, 1998. 295p.
EL-HADDAD, E-S.H.; NOAMAN, M.M. Leaching requirement and salinity threshold for the yield and agronomic characteristics of halophytes under salt stress. Journal of Arid Environments, v.49, p.865-874, 2001.

ESSA, T.A. Effect of salinity stress on growth and nutrient composition of three soybean (Glycine $\max \mathrm{L}$. Merrill) cultivars. Journal of Agronomy \& Crop Science, v.188, p.86-93, 2002.

EYMAR, E.; OKI, L.R.; LIETH, J.H. Continuous measurements of electrical conductivity in growing media using a modified suction probe: initial calibration and potential usefulness. Plant and Soil, v.230, p.67-75, 2001.

GOMES, C. Centro-Oeste concentra plantios de soja no inverno. Londrina: Embrapa Soja, 2005. Available at: $<$ ht t p : / / w w w. c n p s o.e mbrapa.br/alerta/ ver_alerta.php?cod_pagina_sa $=80 \&$ cultura $=1>$ Access 3 Dec. 2005.

INSTITUTO BRASILEIRO DE GEOGRAFIA E ESTATÍSTICA IBGE. Banco de dados agregados. Rio de Janeiro. Available in: <http://www.sidra.ibge.gov.br> Accessed 5 Dec. 2005.

JOLY, R.J. Effects of sodium chloride on the hydraulic conductivity of soybean root systems. Plant Physiology, v.91, p.12621265, 1989.

KAYA, M.D.; IPEK, A.; ÖZTÜRK, A. Effects of different soil salinity levels on germination and seedling growth of safflower (Carthamus tinctorius L.). Turkish Journal of Agriculture and Forestry, v.27, p.221-227, 2003.

KHAN, A.A.; RAO, S.A.; MCNEILLY, T. Assessment of salinity tolerance based upon seedling root growth response functions in corn (Zea mays L.). Euphytica, v.131, p.81-89, 2003.

MAAS E.V. Crop tolerance. California Agriculture, v.38, p.2021, 1984

MAAS, E.V.; GRATTAN, S.R. Crop yields as affected by salinity. In: SKAGGS, R.W.; VAN SCHILFGAARDE, J. (Ed.). Agricultural drainage. Madison: ASA/CSSA/SSSA, 1999. cap.3, p.55-108.

MAAS, E.V.; HOFFMAN, G.J. Crop salt tolerance - current assessment. Journal of Irrigation and Drainage Division, v.103, p.115-134, 1977.

MAGUIRE, J.D. Speed of germination aid in selection and evaluation for seedling emergence and vigor. Crop Science, v.2, p.176-177, 1962.

MARSCHNER, H. Mineral nutrition of higher plants. 2.ed. London: Academic Press, 1995. 889p.

MORAES, G.A.F.; MENEZES, N.L. Desempenho de sementes de soja sob condições diferentes de potencial osmótico. Ciência Rural, v.33, p.219-226, 2003.

MOREIRA, J.A.A.; STONE, L.F.; SILVEIRA, P.M.; GUIMARÃES, C.M. Manejo da irrigação do milho no sistema plantio direto: tensão da água no solo. Santo Antônio de Goiás: Embrapa Arroz e Feijão, 2000. 2p. (Pesquisa em Foco, 36).

MUNNS, R. Comparative physiology of salt and water stress. Plant, Cell and Environment, v.25, p.239-250, 2002.

RHOADES, J.D.; KANDIAH, A.; MARSHALI, A.M. Uso de águas salinas para produção agrícola. Trad. de H.R. GUEYI, J.R. SOUZA e J.E. QUEIROZ. Campina Grande: UFPB, 2000. 117p. (FAO. Estudos de Irrigação e Drenagem, 48).

RIEU, M.; VAZ, R.; CABRERA, F.; MORENO, F. Modelling the concentration or dilution of saline soil-water systems. European Journal of Soil Science, v.49, p.53-63, 1998.

SECRETARIA DA AGRICULTURA, PECUÁRIA E ABASTECIMENTO DO ESTADO DO TOCANTINS SEAGRO. Comparativo da produção anual de grãos. Palmas. Available at: <http://www.seagro.to.gov.br/ v_menu.php?id=131> Accessed 3 Dec. 2005.

SILVA, J.V.; LACERDA, C.F.; COSTA, P.H.A.; ENÉAS FILHO, J.; GOMES FILHO, E.; PRISCO, J.T. Physiological responses of $\mathrm{NaCl}$ stressed cowpea plants grown in nutrient solution supplemented with $\mathrm{CaCl}_{2}$. Brazilian Journal of Plant Physiology, v.15, p.99-105, 2003. 
SINGLETON, P.W.; BOHLOOL, B.B. Effect of salinity on nodule formation by soybean. Plant Physiology, v.74, p.72-76, 1984.

STEPPUHN, H.; GENUCHTEN, M.T.; GRIEVE, C.M. Root-zone salinity: I. Selecting a product-yield index and response function for crop tolerance. Crop Science, v.45, p.209-220, 2005.

TESTER, M.; DAVENPORT, R. $\mathrm{Na}^{+}$tolerance and $\mathrm{Na}^{+}$transport in higher plants. Annals of Botany, v.91, p.503-527, 2003.

TISDALE, S.L.; NELSON, W.L.; BEATON, J.D.; HAVLIN, J.L. Soil fertility and fertilizers. 5.ed. New York: Macmillan Publishing, 1993. 634p.

VAN GENUCHTEN, M.Th. Analyzing crop salt tolerance data: model description and user's manual. Riverside: USSL, 1983. 50p. (Research Report, 120).
WANG, D.; SHANNON, M.C. Emergence and seedling growth of soybean cultivars and maturity groups under salinity. Plant and Soil, v.214, p.117-124, 1999.

WILLADINO, L.; CÂMARA, T.R.; TABOSA, J.N.; ANDRADE, A.G.; GOMES, R.V.; SOUZA, A.J. Avaliação de cultivares de milho em solo salino do semi-árido de Pernambuco. Pesquisa Agropecuária Brasileira, v.29, p.1059-1065, 1994.

Received June 05, 2006 Accepted June 22, 2007 